\title{
How to measure the economic value of ecosystem functions and processes and link such value to the MSP?
}

\author{
Ilona Kamińska ${ }^{1,}$, , Tomasz Zarzycki ${ }^{1}$, Jacek Zaucha ${ }^{2}$ and Dorota Ciołek $^{3}$ \\ ${ }^{1}$ University of Gdansk, Faculty of Oceanography and Geography, Institute of Oceanography, 80-309 \\ Gdansk, Poland \\ ${ }^{2}$ University of Gdansk, Faculty of Economics, Department of Macroeconomics, 80-309 Gdansk, \\ Poland \\ ${ }^{3}$ University of Gdansk, Faculty of Management, Department of Econometrics, 80-309 Gdansk, \\ Poland
}

\begin{abstract}
The paper aims at answering questions on implications of the economic valuation of regulatory ecosystem service in maritime spatial planning. The biogeochemical processes that occur in marine sediments such as denitrification, contribute indirectly, though significantly, benefits to human wellbeing. Such direct and indirect benefits are called ecosystem services. According to the Common International Classification of Ecosystem Services (CICES V5.1) for the Integrated Environmental and Economic Accounting, the case study: ecosystem service lies within the: Section - Regulation \& Maintenance (Biotic); Division - Transformation of biochemical or physical inputs to ecosystems; Group - Mediation of wastes or toxic substances of anthropogenic origin by living processes and Class Bio-remediation by micro-organisms, algae, plants, and animals (Code 2.1.1.1). Marine sediments are economically evaluated mainly as sources of providing services (sand and gravel extraction or space for potential industrial use). Their regulatory function is often neglected in such studies. Therefore, we employed the methodology from the field of ecological economics and assessed the economic value of denitrification of the Gulf of Gdansk. This paper suggests the possible implications of using such data in MSP and discusses the competition sea uses in order to determine the final benefits for society.
\end{abstract}

\section{Ecosystem services and MSP}

Marine spatial planning is considered as a tool of ecosystem based management [1] and requires the most recent baseline maps of ecosystem components. Usually data layers on biomass, species abundance and/or richness (biodiversity) are used, though they are not straightforward indicators of an area value. In several cases more comprehensive approaches have been used, such as Biological Valuation Maps - BVM [2, 3]. BVMs

\footnotetext{
* Corresponding author: oceika@ug.edu.pl
} 
integrate biological features such as abundance of species with additional criteria such as fitness consequences and rarity, though no social dimension is incorporated in such approach.

The goal of marine spatial planning is to spatially and temporarily organize maritime uses so there is no conflict between each other and between them and the marine ecosystem. These activities and uses are possible due to the flow of direct and indirect benefits from ecosystem resources, as well as functions and processes that are called ecosystem services $[4,5]$. Consequently, mapping of marine ecosystem services is an essential issue for preparing environmentally and societally relevant plans for the use of marine resources [6]. Mapping of ecosystem services allow one to integrate biological and ecological valuation maps with social and economic aspects of marine ecosystems.

\subsection{Ecosystem services provided by marine ecosystems}

Marine and coastal ecosystems provide a wide range of goods and services that are fundamental to human well-being. Ecological processes, products and outcomes arising from the interactions of organisms with their environment and their activities in the ecosystem are translated into the terms of goods and services in order to increase the understanding between the science and decision makers or society [7,8]. Despite the fact that the goods and services concept is not free of criticism [9], research in this field has become widely accepted and has developed rapidly in the last decade. Many different methods of categorisation of ecosystem services have been proposed in the literature $[5,10$ 15]. The classification introduced by Beaumont [4], following Millenium Ecosystem Assessment [5] and Hein [15] proposes the division of goods and services into four categories: (i) production services - products obtained from the ecosystem; (ii) regulating services - the benefits obtained from the regulation of ecosystem processes; (iii) cultural services - the nonmaterial benefits which people obtain from ecosystems; and (iv) supporting services - the ones which are necessary for the production of all other ecosystem services, but do not yield direct benefits to humans. Except the four abovementioned categories, an additional group of 'the option use value' services was proposed by Beaumont [4], so that all Total Economic Value (TEV) categories are represented. The detailed definitions of particular goods and services can be found in the earlier referred work of Beaumont [4]. In addition, several case studies, according to this framework, including the Gulf of Gdansk, were preliminarily analysed in terms of the presence of goods and services provided by marine living organisms as a proxy of marine biodiversity.

More recent approaches to classification of ecosystem services started to appear in the literature and policy such as The Economics of Ecosystems and Biodiversity TEEB [16], and the EU-level proposal for the CICES - Common International Classification of Ecosystem Services (http://www.cices.org) developed for the purpose of the EU Biodiversity Strategy implementation by the Mapping and Assessments of Ecosystem Services working group $[17,18]$.

Several approaches became more national or regional in terms of geographical scope, such as the UK National Ecosystem Assessment [19] and the UK National Ecosystem Assessment Follow On [20]; Swedish Environmental Protection Agency [21] for the Baltic Sea and Skagerrak; HELCOM [22], [23] etc. that address marine ecosystem services.

The Common International Classification of Ecosystem Services (CICES) developed from the work on environmental accounting undertaken by the European Environment Agency (EEA). The idea of a common international classification was elaborated, due to the recognition that if ecosystem accounting methods were to be developed and comparisons made, then some standardisation in the way we describe ecosystem services was needed 
[24]. In addition to the need for the standardization in the context of environmental accounting as well as work on mapping (including spatial visualisation), as well as valuing ecosystem services more generally would benefit from more systematic approaches to naming and describing ecosystem services.

\subsection{Regulatory ecosystem services - removal of nitrogen}

Eutrophication is one of the main threats to the biodiversity of the Baltic Sea and is caused by excessive load of nutrients to the marine environment. Eutrophication is driven by a surplus of nitrogen and phosphorus in the sea. Nutrient over-enrichment causes elevated levels of algal and plant growth, increased turbidity, oxygen depletion, changes in species composition and nuisance blooms of algae [25].

The role of microorganisms and other biota in removal of nitrogen as well as ecosystem functions and processes contribute to regulatory services such as mitigation of eutrophication. For the purpose of presented research, only the part of the regulatory services provided by marine processes was analysed. One of the key benefits from marine sediments is the removal mechanism for nitrogen from aquatic systems which mitigates eutrophication. According to CICES this particular service can be classified as: section regulation and maintenance (Biotic); division - transformation of biochemical or physical inputs to ecosystems; group - mediation of wastes or toxic substances of anthropogenic origin by living processes and class - bio-remediation by micro-organisms, algae, plants, and animals (CICES Code 2.1.1.1).

\section{Methodology - economic valuation of ecosystem services}

A number of methodologies have been developed to attempt to quantify the benefits of different ecosystem services [26-29]. Similarly to private market goods, all methods of economic valuation of ecosystem goods and services are found in the theoretical principles of welfare economics. Changes in welfare are being observed through the investigation of people's willingness to pay (WTP) or willingness to accept compensation (WTA) for changes in the level of provision of a particular good or service [30-31]. Some valuation techniques are based on actually observed behaviour data which are known as 'revealed preference' techniques. They include methods that intercept values indirectly from behaviour in surrogate and existing markets, which are assumed to have a direct relationship with the ecosystem good or service being assessed [32-34]. In contrast to the ones described above, other techniques generally known as 'stated preference' are based on rather hypothetical than actual behaviour data. Questions describing hypothetical markets or situations regarding changes in the quality of service provided are asked. The value is inferred from the obtained people's responses [32-34]. Certain techniques can be applied on a broad scale, for many components of TEV, some are applicable to specific issues or impacts, and others are adapted to particular data sources $[35,36]$.

\subsection{Economic valuation of regulatory ecosystem services - removal of nitrogen}

The goal of presented research was to estimate the economic value of mitigation of the effects of eutrophication processes - regulating ecosystem service of the Gulf of Gdansk using a combination of two non-market goods valuation methods, i.e. the Replacement Cost Method (RC) and the Contingent Valuation Method (CVM). For the purpose of the study it was assumed that services balancing the effects of eutrophication are linked with regulating 
nitrogen through denitrification in sediments. The use of a set of direct and indirect methods of economic valuation enabled us to verify the research hypothesis which assumes that the value of mitigating the effects of eutrophication services, estimated on the basis of the replacement cost, is higher than the value expressed by social preferences.

The initial estimation of the economic valuation of removal of nitrogen and mitigation of eutrophication processes using the Replacement Cost Method has been divided into four stages: (I) Identification and quantification of the service regulating the effects of eutrophication understood as balancing the amount of nitrogen through denitrification in sediments; (II) Indicating a substitute for the provided ecosystem service; (III) The economic valuation of mitigation of eutrophication; (IV) Conducting the research using the Contingent Valuation Method necessary for verifying the estimated value.

It is worth remembering that the Replacement Cost Method cannot be assessed as a credible measure of the economic value without performing comparative research using the Contingent Valuation Method - CVM [37-39]. Consequently, the estimation of the economic valuation of balancing the eutrophication effects had been divided into the following research tasks: (I) The analysis of additional substitutes for an ecosystem service; (II) Constructing two valuation scenarios and conducting a Focus Group Interview; (III) Conducting pilot research and verifying the scenarios; (IV) Conducting the main research estimating the socio-economic value of an eutrophication effect balancing service using the CVM; (V) The statistical analysis of survey results; and (VI) The analysis of value changes resulting from the declared preferences in connection with a reduction in the amount of nitrogen in the Gulf of Gdansk and aggregation of the results for the Polish population.

The Contingent Valuation Method, until recently was considered the most controversial method of the environmental valuation. It is used for a broad spectrum of problems since it enables estimating both use and non-use values. The Contingent Valuation Method is based on two assumptions. Firstly, consumers know best what is best for them, and secondly, the market participants are able to reasonably and consciously determine their preferences. This method attempts to translate people's opinions to monetary values. The technique tries to determine the value that people attribute to particular ecosystem goods or services. The way to achieve this goal is to examine peoples' opinions through interviews. Surveys are conducted among a representative group of consumers.

In everyday life it often happens that we realise the real value of something, only when we lose it. The basis for valuation is therefore a fact or even a possibility of losing the value [32]. Consequently, the valuation is expressed by the willingness to cover the costs. Subsequently, the respondents are asked to clearly state how much they are willing to pay for ecosystem services (WTP: Willingness To Pay).There is no market where the services balancing the effects of eutrophication would be the subject of trade. In consequence, the scenario presenting a particular situation in which a respondent is supposed to provide a particular WTP value, should contain enough information and ought to be the most probable. As a rule, the scenario used during the Contingent Valuation Method research informs respondents about the hypothetical, but sometimes real situation of the deteriorating environment.

It was assumed that respondents behave identically to the real market, they are aware of decisions taken, and their consequences, and finally understand the presented situation. Nowadays, most economists agree that the results obtained by this method can be reliable under certain necessary conditions. This method, like any other tool, must be used with full awareness of its shortcomings and limitations.

The survey will took into account the specificity of the examined service, i.e. balancing the effects of eutrophication services in the Gulf of Gdansk ecosystem and the NOAA's recommendations [40]. The process of designing the survey assumes that: (i) the situation in terms of which the respondent makes the transaction will be thoroughly described, (ii) 
factsheet illustrating the effects of eutrophication, used in order to familiarise the surveyed with the valuation scenario, was tested in the pilot research, (iii) the used format of questions was a question about willingness to pay - WTP, (iv) the respondents were informed about the existence of substitutes for the services mentioned in the valuation scenario, (v) following questions about participation in the transaction (yes / no), a question about the reasons for taking a particular decision followed (vi).

The survey consisted of 11 questions plus a section providing information on sociodemographic characteristics of respondents, as for instance age, sex, residence, education, occupation, number of persons constituting the household and monthly net household income. The main survey was carried out at 1000-person representative sample of adult Polish citizens in 2014. Interviews were conducted face-to-face, and performed by the trained interviewers. The representative sample being tested is a random-quota sample whose composition corresponds to the population according to the following features: voivodeship, place of residence (city or village), gender and age. The sizes of individual features were calculated on the basis of the Local Data Bank of the Central Statistical Office. Stratified sampling was used. In randomly chosen locations, the interviewers selected the interviewees ensuring the nationwide representativeness of the sample due to the above-mentioned features.

\section{Results - economic valuation of regulatory ecosystem services - removal of nitrogen}

\subsection{Quantification of the regulating service, the amount of nitrogen removed through denitrification in sediments}

Ecosystem processes responsible for removal of nitrogen from the water column (denitrification) and mitigating the effects of eutrophication roughly utilise 20410 tons of nitrogen (41). This corresponds to ca. $15 \%$ of the total supply of nitrogen from external sources.

\subsection{Indicating a substitute for the provided ecosystem service}

The second stage aimed at indicating the artificial substitute for the service provided by the environment, complying at the same time with the condition that the substitute should be the cheapest one [39]. Consequently, the biological wastewater treatment process on the example of the company Saur Neptun Gdansk S.A. was selected. The company is responsible for the collective water supply and sewage disposal and serves about 500, 000 inhabitants from the area of the city of Gdansk and Sopot.

\subsection{The economic valuation of mitigation of eutrophication by using Replacement Cost Method}

Annually, the sewage treatment plants of the discussed company receive $33640228 \mathrm{~m}^{3}$ of wastewater containing 2795,5 tons of nitrogen [42]. The wastewater is biologically treated, which costs about $3.38 \mathrm{PLN} / \mathrm{m}^{3}$. In the sewage treatment process the nitrogen content is reduced by $85.3 \%$ which corresponds to the removal of 2132,8 tons of nitrogen via process of denitrification. As it was mentioned in point 3.1, the Gulf of Gdansk is responsible for the removal of 20410 tons of nitrogen [41]. It takes all phases in biological wastewater 
treatment (incl. primary mechanical treatment) to perform the nutrients reduction, therefore it can be assumed that the total cost of treatment per $1 \mathrm{~m}^{3}$ of wastewater can be used in the nitrogen reduction. The estimated value of service that is being discussed is approximately assessed at 1088099231 PLN per year. And removal of one tonne of nitrogen costs about 53 312,06 PLN annually.

\subsection{Verification of RCM results by conducting Contingent Valuation Method (CVM)}

The results of the survey allowed mainly to estimate the economic value of the ecosystem service, i.e. is the denitrification process occurring in the Gulf of Gdansk ecosystem. However, the wide range of information obtained in the study made it also possible to find an answer to the question how the declared WTP depends on various sociological, economic and demographic factors. In order to investigate the impact on the WTP value of these variables, the approach used by Ressurreição [43] was applied. An econometric model explaining the natural logarithm of the WTP amount declared by the respondents was estimated [44].

Based on the results of the survey, we can determine the average WTP value declared by respondents, not protesters. This is 21.14 PLN per person with a $95 \%$ confidence interval $(17.33 ; 24.95)$. Taking into account the average income of respondents, this would be about $0.78 \%$ of the average monthly salary.

When interpreting the results of the model, it should be stated that the income of respondents had a high positive impact on the declared value of WTP, the impact is statistically significant at the lowest level of significance regardless of the specification of the model. This means that people with higher incomes are more inclined to get involved in financing the analysed project. A positive statistically significant impact of the level of education has been demonstrated. People with higher education are more likely to incur costs related to the protection of the Gulf of Gdansk. It also turned out that among the surveyed people, urban residents declared smaller amounts than the residents of rural areas, but assuming the same level of income, education, age and number of members in the family.

Analysing the impact of environmental awareness of respondents, it was noticeable that the more negative effects a respondent experienced, the greater the amount they were willing to declare. In addition, knowledge of each of the natural regulatory functions of the Gulf of Gdansk contributed to a greater tendency to co-finance - the most important function turned out to be 'maintaining the gas and climate balance'. It was also shown that a respondent's region of residence was significant for the declared WTP amounts. People living in the following voivodeships: Masovia, Podlaskie, Silesia, Warmia-Masuria, Greater Poland, and Lubusz declared lower values than the national average. Holy Cross Province and West Pomerania - on the national average level. The other voivodeships indicated a greater tendency to co-finance the analysed project

The non-protesters group [45] constituted $69.8 \%$ of the respondents. Therefore, treating the sample on which the survey was conducted as a representative sample, we may assume that a similar part of the entire adult Polish population would be willing to incur such a oneoff payment to finance technological solutions replacing the lost natural self-cleaning functions of the Gulf of Gdansk. Data from the Polish Statistical Office shows that in 2013, the population above 20 years of age was $34,482,874$ people. If $69.8 \%$ of those people paid 21.14 PLN then the amount collected would be 508819978 PLN. Taking into account the $95 \%$ confidence interval, this would be between 417,210,334 PLN and 600,429,622 PLN. 


\section{Discussion - how to link the economic value of ecosystem functions and processes to the MSP?}

The use of a set of direct and indirect methods of economic valuation enabled us to positively verify the research hypothesis which assumed that the value of mitigating the effects of eutrophication services, estimated on the basis of replacement cost, is higher than the value expressed by social preferences. The results of the survey made it possible first of all to estimate the economic value of the ecosystem service, i.e. is the denitrification process taking place in the Gulf of Gdansk ecosystem, according to the respondents' opinions. The average value of participating in the costs of this service was declared by respondents at the level of 21.14 PLN per person with a 95\% confidence interval (17.33; 24.95). The generalised total value of WTP for all residents of Poland is 508819978 PLN, which means about 87 thousand PLN per $\mathrm{km}^{2}$ of the Gulf of Gdansk sediments [44]

Compared to the value of the service calculated on the basis of replacement costs, the removal of 20,410 t of nitrogen means an expenditure of approx. 1088099231 PLN. In simplified terms, denitrification services are provided by sediments cost-free. Theoretically, the use of sediments for bioremediation may give rise to an alternative cost (e.g. a ban on erecting structures located on the bottom). In Polish conditions in internal and territorial waters it is not possible to build wind farms, and mariculture in the Gulf of Gdansk is not a viable alternative to seabed. There are also no studies on external costs generated by such sediments. Therefore, the zero value of the alternative cost was assumed. In view of the above, it is enough to divide the amount by the surface the Gulf of Gdansk sediments $(5,852 \mathrm{~km} 2$ of sediments) to obtain the value of the spatial rent of 185.9 thousand PLN per $\mathrm{km} 2$ of sediments for 1 year. The WTP value per ha of sediments is significantly lower than the previously calculated replacement costs $(87,000$ PLN per km2). The survey used the elicitation format, i.e. one-off payment, which makes it very difficult to compare with the substitution costs results by a particular substitute for nitrogen removal on land expressed in PLN per year. The value declared by the respondents should therefore be 'sufficient' to solve the problem of eutrophication with this one payment. This means a significant underestimation of the value of ecosystem services by Polish citizens. The degree of supply of organic pollutants to the Baltic is decreasing, but unfortunately to a small extent, so the Gulf of Gdansk function is needed all the time. Despite these differences, the way to the practical use of the study results is not closed.

This study shares knowledge on the economic value of maritime services (in this case regulatory services) to the maritime policy. This knowledge can be used to support actions for the sustainable use of the seabed and its mineral resources, complementing the existing bottom maps, indicating selected areas of the seabed important from the viewpoint of the economic development and protection of ecosystem services. Maps supplemented with data on economic and ecological value of ecosystem services will be the starting point for spatial planning in maritime areas and proper management of seabed areas. The estimated economic value of maritime services can be used as a tool to raise environmental awareness among maritime decision-makers and users, and this may result in fewer conflicts between the economic exploitation of the sea and the needs of the environmental protection.

To make the marine spatial plans deciding upon conflicting uses, the monetary value of various benefits might provide a useful insight and guidelines. Nonetheless, at the same time they can bias planning towards quantifiable benefits only. Many research questions are still pending. What form of the results of economic valuation is needed to support a knowledge based (evidence based) decision in marine spatial planning? To what extent will the understanding of space requirements change if we introduce economic values to MSP? 


\section{Acknowledgments}

The paper presents the outcomes of the research financed by the Polish National Science Centre under the project: 'Economy of maritime space' 2015/17/B/HS4/00918 as well as 'Economic valuation of balancing the effects of eutrophication processes - regulating ecosystem services of Gulf of Gdansk in the context of promoting sustainable development' granted by decision number DEC-2012/05/N/HS4/00960. We would like to also thank the company Saur Neptun Gdańsk for sharing the data with authors.

\section{References}

1. EU Directive 2008/56/EC of the European Parliament and of the Council of 17 June 2008 establishing a framework for community action in the field of marine environmental policy (Marine Strategy Framework Directive) (2008)

2. S. Derous, M. Austen, S. Claus, N. Daan, J.C. Dauvin, K. Deneudt, J. Depestele, N. Desroy, H. Heessen, K. Hostens, A.H. Marboe, A.K. Lescrauwaet, M. Moreno, I. Moulaert, D. Paelinckx, M. Rabaut, H. Rees, A. Ressureição, J. Roff, P.T. Santos, J. Speybroeck, E.W.M. Stienen, A. Tatarek, R. Ter Hofstede, M. Vincx, T. Zarzycki, S. Degraer, Building on the concept for marine biological valuation with respect to translating it to a practical protocol: Viewpoints derived froma joint ENCORAMARBEF initiative. Oceanologia 49, 4 (2007)

3. T. Zarzycki, Ecological and Socio-Economic Valuation of Marine Biodiversity of the Gulf of Gdańsk, PhD thesis, Faculty of Oceanography and Geography, University of Gdansk (2012)

4. N.J. Beaumont, M.C. Austen, J.P. Atkins, D. Burdon, S. Degraer, T.P. Dentinho, S. Derous, P. Holm, T. Horton, E. van Ierland, A..H. Marboe, D.J. Starkey, M. Townsend, T. Zarzycki, Identification, definition and quantification of goods and services provided by marine biodiversity: Implications for the ecosystem approach, Marine Pollution Bulletin 54, 253-265 (2007)

5. Millennium Ecosystem Assessment. Island Press, Washington DC (2005)

6. C.M. Holmlund, M. Hammer, Ecosystem services generated by fish populations, Ecol. Econ. 29, 253-268 (1999)

7. E.M. Borgese, The economics of the common heritage, Ocean and Coastal Management 43, 763-779 (2000)

8. J.M. Wesławski, E. Andrulewicz, L. Kotwicki, E. Kuzebski, A. Lewandowski, T. Linkowski, S.R. Massel, S. Musielak, K. Olanczuk-Neyman, J. Pempkowiak, H. Piekarek-Jankowska, T. Radziejewska, G. Różynski, I. Sagan, K.E. Skóra, K. Szefler, J. Urbanski, Z. Witek, M. Wołowicz, J. Zachowicz, T. Zarzycki, Basis for a valuation of the Polish Exclusive Economic Zone of the Baltic Sea: Rationale and quest for tools, Oceanologia 48, 1, 145-167 (2006)

9. L. Lewan, T. Söderqvist, Knowledge and recognition of ecosystem services among the general public in a drainage basin in Scania, Southern Sweden, Ecol. Econ. 42, 459467 (2002)

10. R. Costanza, R. d'Arge, R.S. de Groot, S. Farber, M. Grasso, B. Hannon, K. Limburg, S. Naeem, R. O'Neill, J. Paruelo, R. Raskin, P. Sutton, M. van den Belt, The value of the world's ecosystem services and natural capital, Nature 387, 253-260 (1997) 
11. D. Pimentel, C. Wilson, C. McCullum, R. Huang, P. Dwen, J. Flack, Q. Tran, T. Saltman, B. Cliff, Economic and environmental benefits of biodiversity, Bioscience 47, 11, 747-757 (1997)

12. K.C. Ewel, R.R. Twilley, J.E. Ong, Different kinds of mangrove forest provide different goods and services, Global Ecol. Biogeogr. 7, 83-94 (1998)

13. F. Moberg, C. Folke, Ecological goods and services of coral reef ecosystems, Ecol. Econ. 29, 215-233 (1999)

14. R.S. de Groot, M.A. Wilson, R.M.J. Boumans, A typology for the classification, description and valuation of ecosystem functions, goods and systems. Ecol. Econ. 41, 3, 393-408 (2002)

15. L. Hein, K. Koppen, R. de Groot, E. Ierland, Spatial scales, stakeholders and the valuation of ecosystem services. Ecol. Econ. 57, 209-228 (2006)

16. The economics of ecosystems and biodiversity: mainstreaming the economics of nature: a synthesis of the approach, conclusions and recommendations of TEEB (2010)

17. J. Maes, A. Teller, M. Erhard, C. Liquete, L. Braat, P. Berry, B. Egoh, P. Puydarrieux, C. Fiorina, F. Santos, M.L. Paracchini, H. Keune, H. Wittmer, J. Hauck, I. Fiala, P.H. Verburg, S. Condé, J.P. Schägner, J. San Miguel, C. Estreguil, O. Ostermann, J.I. Barredo, H.M. Pereira, A. Stott, V. Laporte, A. Meiner, B. Olah, E. Royo Gelabert, R. Spyropoulou, J.E. Petersen, C. Maguire, N. Zal, E. Achilleos, A. Rubin, L. Ledoux, C. Brown, C. Raes, S. Jacobs, M. Vandewalle, D. Connor, G. Bidoglio Mapping and Assessment of Ecosystems and their Services. An analytical framework for ecosystem assessments under action 5 of the EU biodiversity strategy to 2020. Publications office of the European Union, Luxembourg (2013)

18. MAES, Indicators for mapping ecosystem services. 2nd MAES Working Paper. European Union, doi: 10.2779/75203 (2014)

19. UK National Economic Assessment (UK NEA) The UK National Ecosystem Assessment. Technical Report. UNEP-WCMC, Cambridge (2011)

20. K. Turner, M. Schaafsma, M. Elliott, D. Burdon, J. Atkins, T. Jickells, P. Tett, L. Mee, van S. Leeuwen, S. Barnard, T. Luisetti, L. Paltriguera, G. Palmieri, J. Andrews, UK National Ecosystem Assessment Follow-on. Work Package Report 4: Coastal and marine ecosystem services: principles and practice. UNEP-WCMC, LWEC, UK (2014)

21. T. Söderqvist, L. Hasselström, The economic value of ecosystem services provided by the Baltic Sea and Skagerrak. The Swedish Environmental Protection Agency Report 5874 (2008)

22. HELCOM, Ecosystem Health of the Baltic Sea 2003-2007: HELCOM Initial Holistic Assessment. Balt. Sea Environ. Proc. No. 122. (2010)

23. B. Hasler, Marine Ecosystem Services: Marine Ecosystem Services in Nordic Marine Waters and the Baltic Sea - Possibilities for Valuation, Nordic Council of Ministers, (2016)

24. R. Haines-Young, M.B. Potschin, Common International Classification of Ecosystem Services (CICES) V5.1 and Guidance on the Application of the Revised Structure. Available from www.cices.eu CICES (2018)

25. HELCOM, Sources and pathways of nutrients to the Baltic Sea. Baltic Sea Environment Proceedings No. 153 (2018)

26. M.M. Hufschmidt, D.E. James, A.D. Meister, B.T. Bower, J.A. Dixon, Environment, natural systems, and development: an economic valuation guide. Baltimore, EUA: Johns Hopkins University Press (1983)

27. J. Braden, C. Kolstad, (Eds.), Measuring the Demand for Environmental Quality. Elsevier Science Pub., New York (1991)

28. W.M. Hanemann, Preface. In: Pricing the European Environment, S. Navrud (ed.), Scandinavian University Press, Oslo (1992) 
29. A.M. Freeman, The measurement of environmental and resource values. Washington: Resource for the Future (1993)

30. J.A. Dixon, L.F. Scura, R.A. Carpenter, P.B. Sherman, Economic Analysis of Environmental Impacts. London: Earthscan Publications Ltd. (1994)

31. W.M. Hanemann, Willingness to pay and willingness to accept: How much can they differ? American Economic Review 81, 3, 635-647 (1991)

32. J. Shogren, J. Hayes, Resolving differences in willingness to pay and willingness to accept: A reply. American Economic Review 87, 241-2 (1997)

33. T. Żylicz, Ekonomia wobec problemów środowiska przyrodniczego, PWN, Warszawa (1989)

34. T. Żylicz, Ekonomia Srodowiska i Zasobów Naturalnych, PWE, Warszawa (2004)

35. Integrated Coastal Zone Management: Review of Progress in Selected OECD Countries, OECD, Paris (2007)

36. S. Pagiola, P. Agostini, J. Gobbi, C. de Haan, M. Ibrahim, E. Murgueitio, E. Ramírez, M. Rosales, J.P. Ruíz, Paying for biodiversity conservation services in agricultural landscapes. Environment Department Paper No. 96. Washington: World Bank (2004)

37. L.A. Shabman, S. Batie, Economic Value of Natural Coastal Wetlands: A Critique. Coastal Zone Management Journal, 4, 231-247 (1978)

38. A.M. Freeman, The Measurement of Environmental and Resource Values - Theory and Methods. 2nd Edition. Washington, D.C.: Resources for the Future (2003)

39. S. Sundberg, Replacement costs as economic values of environmental change: $A$ review and an application to Swedish sea trout habitats. Swedish Environmental Protection Agency (2004)

40. K. Arrow, R. Solow, P. Portney, E. E. Learner, R. Radner, H. Schuman, Report of the NOAA Panel on Contingent Valuation, National Oceanic and Atmospheric Administration (1993)

41. B. Graca, Dynamika przemian azotu I fosforu w strefie kontaktu wody z osadem dennym w Zatoce Gdańskiej. Wydawnictwo Uniwersytetu Gdańskiego, Gdańsk (2009)

42. SNG, Saur Naptun Gdansk, pres. comm. (2014)

43. A. Ressurreição, J. Gibbons, P.T. Dentinnho, M. Kaiser, R. Santos, G. Edward-Jones, Economic valuation of species loss in the open sea, Ecological Economics, 70, 4, 729$739(2011)$

44. I. Wrześniewska, D.Ciołek, T. Zarzycki, Modelowanie ekonomicznej wartości denitryfikacji jako jednej z usług ekosystemowych Zatoki Gdańskiej z wykorzystaniem WTP, Journal of Management and Finance 13, 4/2 (2015)

45. J. Halstead, A. Luloff, T. Stevens, Protest Bidders in Contingent Valuation, Northeastern Journal of Agricultural and Resource Economics 21,160-169 (1992) 